International Journal of Business Management and Economic Review

Vol. 3, No. 04; 2020

ISSN: 2581-4664

\title{
THE EFFECT OF LEARNING ORGANIZATION, OCCUPATIONAL SELF-EFFICACY AND KNOWLEDGE MANAGEMENT ON LAND DISPUTE HANDLING SKILL AND ITS IMPACT ON EMPLOYEE PERFORMANCE OF NATIONAL LAND BOARD REGIONAL OFFICE IN ACEH
}

\author{
Wahyu Ardiansyah, Said Musnadi and Syafruddin \\ Management Department, Universitas Syiah Kuala, Indonesia \\ http://doi.org/10.35409/IJBMER.2020.3191
}

\begin{abstract}
The purpose of this study was to test the effect of learning organization, occupational selfefficacy, and knowledge management on the land dispute handling skill and its impact employee performance. The population in this study was all employees of the National Land Board Regional Office in Aceh (BPN Aceh), totaling 125 people. Sample was taken by census method, so the entire population was sampled as many as 125 respondents. The result showed that learning organization affected land dispute handling skill, occupational self-efficacy affects the land dispute handling skill, knowledge management affects the land dispute handling skill, learning organization did not affect the performance of employees, occupational self-efficacy affected the performance of employees, knowledge management affected the performance of employees, land dispute handling skill affected the performance of employees, learning organization affected the performance of employees through the land dispute handling skill, occupational self-efficacy affected the performance of employees through the land dispute handling skill, and knowledge management affected the performance of employees through the land dispute handling skill. So from the 10 hypotheses, there was one not accepted. The knowledge management had the greatest contribution in improving the employee performance. The land dispute handling skill variable acted as partial mediator and also full mediator in model. All these findings verified the research model formulation and this can contribute to update the theories especially in the management field, and as a reference for the practitioners as well especially for BPN Aceh to reset their policies and strategies. The research novelty lies in the use of land dispute handling skill variable as the specificity of employee skill in BPN Aceh. The limitation resides in the amount of variables and object scope.
\end{abstract}

Keyword: Knowledge Management, Occupational self-efficacy, Learning Organization, Land Dispute Handling Skill, Employee Performance.

\section{INTRODUCTION}

Individual needs in an organization are always evolving at any time, and the phenomenon of the information age is shifting the needs of individuals and organizations from material to information. Marked by $70 \%$ of employees in developed countries the phenomenon that occurs nationally is that there are still many land disputes involving knowledge workers. There is a need 


\section{International Journal of Business Management and Economic Review}

Vol. 3, No. 04; 2020

ISSN: 2581-4664

for knowledge management to be applied within the organization. This indicates that information internalized into knowledge is the most useful resource at the moment and the phenomenon is seen that information, especially knowledge, becomes so necessary as a means of learning by each individual or organization to be able to fulfill and guide it in thinking, doing activities so as to produce more positive performance (Azhari, Musnadi and Tabrani, 2017)

Besides that, all employees at the National Land Board Regional Office in Aceh (BPN Aceh) have been equipped with knowledge relating to the use of information technology and statistics, so that each employee of the BPN Aceh already has basic competence regarding the use of statistics in life. The presence of employees in the organization becomes very important where employees have a very strategic role in achieving organizational goals, namely through the performance. Nevertheless the success of an employee is not only determined by the employee itself, but also by everyone in the organization.

There are several determinant variables that are considered in affecting the employee performance. Beside employee Skill, especially those related to overcoming land conflicts (Yousef, 2000), there are also the knowledge management variable (Pérez López, Manuel Montes Peón and José Vazquez Ordás, 2005); (Goel et al., 2010) that must be possessed by an organization, the existence of a learning organization, and also the self-efficacy (Ningtyas, Suryono and Sukanto, 2014). Self-efficacy is an individual beliefs about his ability to organize, do a task, achieve a goal, produce something and implement actions to achieve certain skills. Discussions related to occupational self efficacy and the development of the Self-Efficacy Scale in Career Self-Making Decision have been carried out (CDMSE; (Taylor and Betz, 1983), specifically the self-efficacy theory discussed by (Bandura, 1993). But the discussion of selfefficacy is mostly related to the decision to determine the carrier path. But an explanation of how occupational self-efficacy (Jex et al., 2001) avoiding carrer indecision is to be an important component of why companies encourage employees to improve self-efficacy associated with professionalism. And, towards career indecision had not been much discussed.

\section{LITERATURE REVIEW Employee Performance}

Performance is the result or level of overall success of a person during a certain period in carrying out the task compared with the standard of work, targets or targets or criteria that have been determined in advance and have been agreed upon (Rivai and Sagala, 2014). Rivai further stated that performance does not stand alone but is related to job satisfaction and compensation, influenced by the skills, abilities and characteristics of individuals. In other words, performance is determined by ability, desire and environment. Therefore, in order to have good performance, a person must have a high desire to do and know the work and can be improved if there is a match between work and ability (Salwa, Away and Tabrani, 2018).

\section{Land Dispute Handling Skill (Employee Skill)}

Land dispute handling skill on this research is the specificity of employee skill. Land Disputes, hereinafter referred to as disputes, are land disputes between individuals, legal entities or institutions which do not have a broad sociopolitical impact. Disputes usually start from situations where there are parties who feel disadvantaged by other parties. This is preceded by subjective and closed feelings of dissatisfaction that can be experienced by individuals or groups. 


\section{International Journal of Business Management and Economic Review}

Vol. 3, No. 04; 2020

ISSN: 2581-4664

Feelings of dissatisfaction will surface when a conflict of interest occurs. Those who feel aggrieved will express their dissatisfaction with the second party.

\section{Learning Organization}

According to (Stata, 1989) stated that learning organization occurs through the sharing of insights, knowledge and mental models that are built based on past knowledge and experience. (Khandekar and Sharma, 2006) defined learning organization as the organization that facilitates learning for all members of their organization and continuously transform themselves. Learning organization is the process of gaining individual and group knowledge that is willing to apply it to their work in making decisions and influencing each other as dynamic capabilities as a source of competitive advantage (Khandekar and Sharma, 2006).

\section{Occupational Self-efficacy}

Self-efficacy can be broadly defined as individuals who believe in the ability they have to organize and carry out the actions needed to produce certain achievements (Bandura, 1993). Self-efficacy can be generally analyzed as a path (Scholz et al., 2002) or in certain contexts, for example, work (Bandura, 1993). Although self-efficacy in general is a predictor of important things that produce positive values in several parts of human resource development (Kamen $e t$ al., 2013); (Mystakidou et al., 2013),

\section{Knowledge Management}

(Jønsson, Jain and Jeppesen, 2013) stated that knowledge management refers to the various practices and techniques used by organizations to create, share and utilize knowledge to achieve organizational goals. The view of knowledge as a source of competitive advantage stems from an organization's resource-based perspective derived primarily from resource theory and internal capabilities. Thus it can be said that if knowledge is a cognitive resource it might be influenced by the cognitive style of senior managers who are responsible for the creation and dissemination of knowledge throughout the organization. (Yasir and Majid, 2017)

\section{Research paradigm}

The research paradigm is formulated in the figure below.

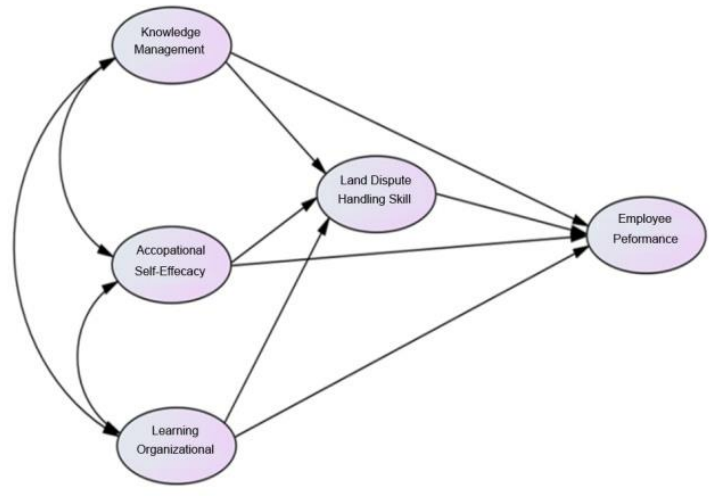


Vol. 3, No. 04; 2020

ISSN: 2581-4664

Figure 1. Research Paradigm

\section{Hypothesis}

Based on the phenomena and from the theoretical basis previously stated, then some hypotheses are stated as follows:

H1 : Learning organization affects land dispute handling skill in BPN Aceh.

$\mathrm{H} 2$ : Occupational self-efficacy affects the land dispute handling skill in BPN Aceh.

H3 : Knowledge Management affects the land dispute handling skill in BPN Aceh.

$\mathrm{H} 4$ : Learning organization affects the performance of employees in BPN Aceh

H5 : Occupational self-efficacy affects the performance of employees BPN Aceh.

H6 : Knowledge Management affects the performance of employees in BPN Aceh.

$\mathrm{H} 7$ : Land dispute handling skill affects the performance of employees in BPN Aceh.

H8 : Learning organization affects the performance of employees in BPN Aceh through the land dispute handling skill

H9 : Occupational self-efficacy affects the performance of employees in BPN Aceh through the land dispute handling skill

H10: Knowledge Management affects the performance of employees in BPN Aceh through the land dispute handling skill

\section{RESEARCH METHOD}

\section{Research Object and Location}

This research was conducted at the Regional Office of the National Land Board in Aceh (BPN Aceh). The Office is located in Banda Aceh City.

\section{Sample}

The population in this study is all employees of the BPN Aceh, totaling 125 employees. Sampling was taken using the census method so the sample amount is equal with the population amount.

\section{Data analysis method}

Data obtained was processed by the structural equation model technique, which is a multivariate statistical analysis technique to be able to analyze not only the influence between variables, but also the relationship of variables with their respective indicators. The criteria for accepting Ha are Critical Ratio (CR) $>1.96$ and Probability value $(\mathrm{P})<0.05$.

\section{RESULT AND DISCUSSION}

\section{Loading Factor}

The loading factor for validity test result can be seen in the following figure and table: 
Vol. 3, No. 04; 2020

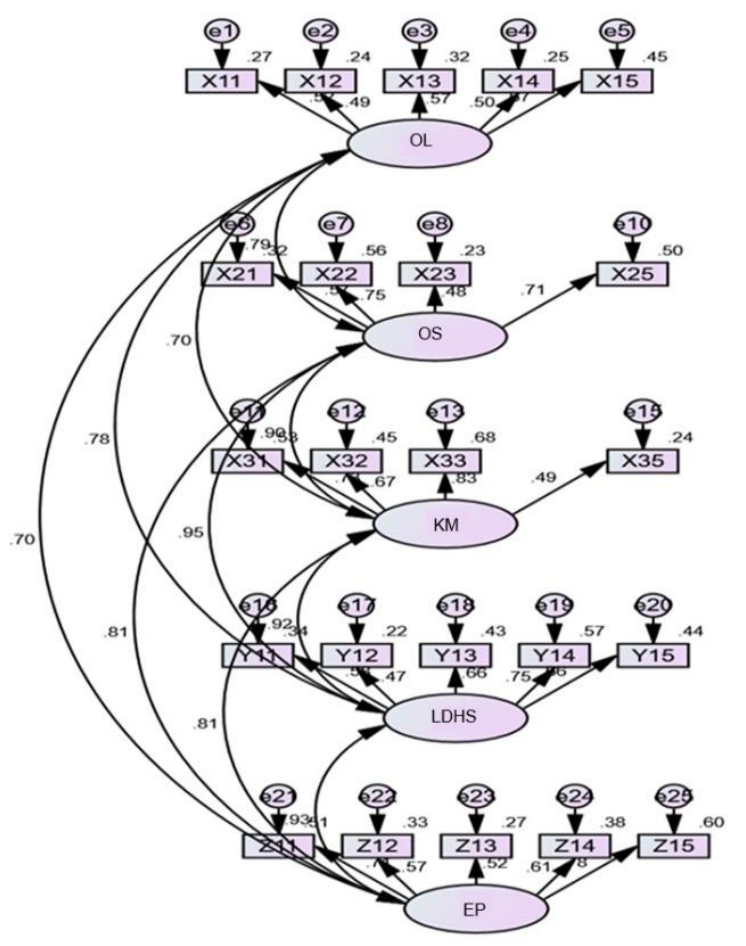

Figure 2. Confirmatory Factor Analysis (CFA)

Measurement test result indicates that several indicators of research variable have a loading factor value below 0.5 . The following table is the result of a net measurement test which can later be included in structural testing.

Table 1. Loading Factor

\begin{tabular}{|l|l|l|l|l|}
\hline No & Indicator & & Variable & Estimate \\
\hline 1 & X11 & $<---$ & LO & .222 \\
\hline 2 & X12 & $<---$ & LO & .490 \\
\hline 3 & X13 & $<---$ & LO & .566 \\
\hline 4 & X14 & $<---$ & LO & .495 \\
\hline 5 & X15 & $<---$ & LO & .670 \\
\hline 6 & X21 & $<---$ & OS & .568 \\
\hline 7 & X22 & $<---$ & OS & .748 \\
\hline 8 & X23 & $<---$ & OS & .478 \\
\hline 9 & X25 & $<---$ & OS & 706 \\
\hline 10 & X31 & $<---$ & KM & .728 \\
\hline 11 & X32 & $<---$ & KM & .667 \\
\hline 12 & X33 & $<---$ & KM & .825 \\
\hline
\end{tabular}


Vol. 3, No. 04; 2020

ISSN: 2581-4664

\begin{tabular}{|l|l|l|l|l|}
\hline No & Indicator & & Variable & Estimate \\
\hline 13 & X35 & $<---$ & KM & .491 \\
\hline 14 & Y11 & $<---$ & LDHS & 582 \\
\hline 15 & Y12 & $<---$ & LDHS & .472 \\
\hline 16 & Y13 & $<---$ & LDHS & .656 \\
\hline 17 & Y14 & $<---$ & LDHS & .754 \\
\hline 18 & Y15 & $<---$ & LDHS & .665 \\
\hline 19 & Z11 & $<---$ & EP & .714 \\
\hline 20 & Z12 & $<---$ & EP & .572 \\
\hline 21 & Z13 & $<---$ & EP & .222 \\
\hline 22 & Z14 & $<---$ & EP & .615 \\
\hline 23 & Z15 & $<---$ & EP & .776 \\
\hline
\end{tabular}

Table 1 shows the loading factors of all indicators in the model. The values have met the requirements for further processing because they have a loading factor $>0.5$.

Table 2. Goodness of Fit Criteria

\begin{tabular}{|l|l|l|l|}
\hline Size Index Criteria & Cut-off Value & Analysis Result & Model Evaluation \\
\hline Chi Square & $\begin{array}{l}\text { Expected to be } \\
\text { small }\end{array}$ & 394.722 & Fit \\
\hline CMIN / DF & CMIN / DF $<2$ & 1.762 & Fit \\
\hline GFI & $>0.90$ & 0.908 & Fit \\
\hline AGFI & $>0.90$ & 0.863 & Not Fit \\
\hline RMSEA & $\leq 0.08$ & 0.072 & Fit \\
\hline IFI & $>0.90$ & 0.872 & Fit \\
\hline
\end{tabular}

Because IFI criteria for measuring model eligibility have been passed, there is no need to modify the model considering other criteria such as RMSEA, CMIN/DF has fulfilled the model eligibility requirements

\section{Structural Analysis for Direct Effect}

The result of structural test conducted have produced the information needed to answer hypotheses that have been built before whether proven or not. Figure 3 below illustrates the influence between variables: 
Vol. 3, No. 04; 2020

ISSN: 2581-4664

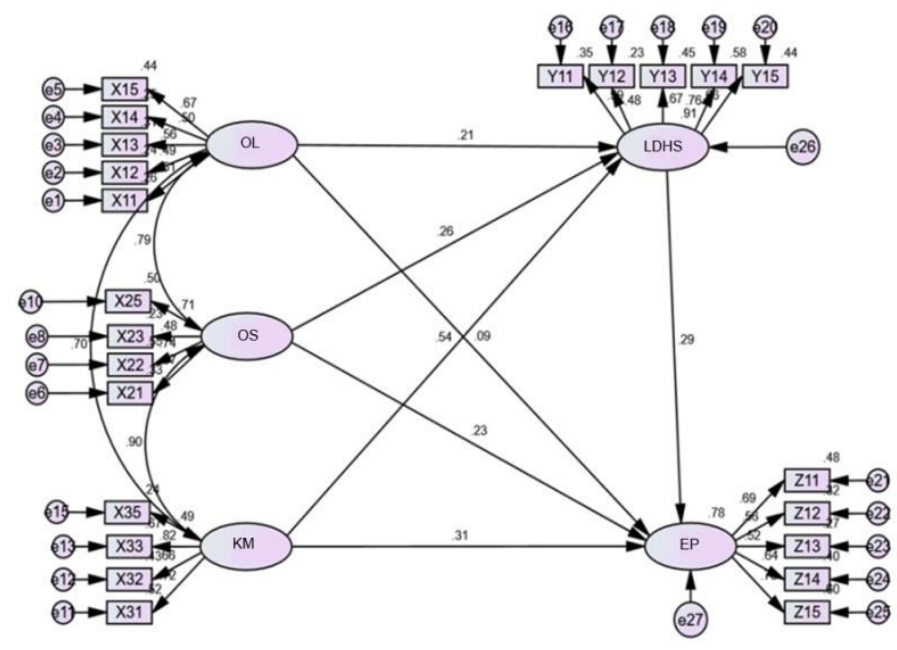

Figure 3. Structural Equation Model

The Figure 3 explains the influence of each variable, namely learning organization, Occupational Self-efficacy, and knowledge management on land dispute handling skill and Employee Performance. An overview of all hypothesis testing together with the results can be seen in the following Table.

Table 3. Direct Hypothesis Result

\begin{tabular}{|c|l|l|l|l|}
\hline No & Hypothesis & $\begin{array}{l}\text { CR Cut } \\
\text { off }>\mathbf{1 . 9 6}\end{array}$ & $\begin{array}{l}\text { P value } \\
\text { Cut off }<\mathbf{0 . 0 5}\end{array}$ & Information \\
\hline 1 & $\begin{array}{l}\text { There is an effect of Learning Organization } \\
\text { on the land dispute handling skill }\end{array}$ & 2.520 & 0.011 & Accepted \\
\hline 2 & $\begin{array}{l}\text { There is an effect of occupational self- } \\
\text { efficacy in the work of land dispute } \\
\text { handling skill }\end{array}$ & 2.519 & 0.012 & Accepted \\
\hline 3 & $\begin{array}{l}\text { There is an effect of Knowledge } \\
\text { Management on the land dispute handling } \\
\text { skill }\end{array}$ & 2.977 & 0.003 & Accepted \\
\hline 4 & $\begin{array}{l}\text { There Is No Effect of Learning } \\
\text { Organization On Employee Performance }\end{array}$ & 0.644 & 0.519 & Not ccepted \\
\hline 5 & $\begin{array}{l}\text { There is an effect of occupational self- } \\
\text { efficacy on employee performance }\end{array}$ & 5.222 & $* * *$ & Accepted \\
\hline 6 & $\begin{array}{l}\text { There is an Influence of Knowledge } \\
\text { Management on Employee Performance }\end{array}$ & 5.219 & $* * *$ & Accepted \\
\hline 7 & $\begin{array}{l}\text { There is an effect of Land dispute handling } \\
\text { skill on Employee Performance }\end{array}$ & 5.224 & $* * *$ & Accepted \\
\hline
\end{tabular}


Vol. 3, No. 04; 2020

ISSN: 2581-4664

It can be seen from the 7 direct hypotheses that there is 1 (one) hypothesis which is not significant, namely the effect of Learning Organization on Employee Performance because it has a CR value of 0.644 and a $P$ value of 0.519 that does not meet the minimum requirements of the hypothesis acceptance. In other words, the other independent variables namely learning management and Occupational Self-efficacy have an influence to increase the dependent variable, namely employee performance as long as the independent variable can be improved by the leaders/ managers of the BPN Aceh.

\section{Structural Analysis for Indirect Effect}

The following is an indirect hypothesis conclusion that is the influence of learning organization occupational self-efficacy, and knowledge management on Employee Performance at the BPN Aceh through land dispute handling skill as shown in Table 4 below:

Table 4. Indirect Hypothesis Result

\begin{tabular}{|l|l|l|l|l|l|}
\hline No & Indirect Hypothesis & $\begin{array}{l}\mathrm{P} \text { value } \\
<0.05\end{array}$ & Beta & Information & $\begin{array}{l}\text { The Role } \\
\text { of } \\
\text { Mediation }\end{array}$ \\
\hline 1 & $\begin{array}{l}\text { The effect of Learning Organization on } \\
\text { Employee Performance through Land } \\
\text { Dispute Handling Skill }\end{array}$ & 0.0230 & $06.1 \%$ & Accepted & $\begin{array}{l}\text { Full } \\
\text { Mediating }\end{array}$ \\
\hline 2 & $\begin{array}{l}\text { The effect of Occupational Self-Efficacy } \\
\text { on Employee Performance through Land } \\
\text { Dispute Handling Skill }\end{array}$ & 0.0235 & $07.6 \%$ & Accepted & $\begin{array}{l}\text { Partial } \\
\text { Mediating }\end{array}$ \\
\hline 3 & $\begin{array}{l}\text { The effect of Knowledge Management } \\
\text { on Employee Performance through Land } \\
\text { Dispute Handling Skill }\end{array}$ & 0.009 & $15.7 \%$ & Accepted & $\begin{array}{l}\text { Partial } \\
\text { Mediating }\end{array}$ \\
\hline
\end{tabular}

From Table 4 it can be seen that the influence of knowledge management and occupational selfefficacy on employee performance both directly and through the land dispute handling skill are significant, so the role of land dispute handling skill here is as a partial mediator variable.

But, the effect of organizational learning on employee performance directly is insignificant while the effect if through land dispute handling skill is significant, so the role of land dispute handling skill here as a full mediator variable. The results of this study are in line with research conducted by (Bandura, 1993) which stated that learning organization is culture-specific in an organization to continue to acquire new knowledge and knowledge sharing among its employees.

\section{CONCLUSION}

1.The Influence of Knowledge Management (KM), Occupational Self-Efficacy (OS), and Learning Organization (LO) on Land Dispute Handling Skill (LDHS) shows the CR value and $\mathrm{p}$ value that have fulfilled the requirements for $\mathrm{HA}$ acceptance, namely $\mathrm{CR}$ value greater than 1.96 and the probability that smaller than 0.05 . Thus it can be stated that the Effect of 


\section{International Journal of Business Management and Economic Review}

Vol. 3, No. 04; 2020

ISSN: 2581-4664

Knowledge Management (KM), Occupational Self-Efficacy (OS), and Learning Organization (LO) on Land Dispute Handling Skill (LDHS) are significant.

2. The influence of Knowledge Management (KM), Occupational Self-Efficacy (OS), on the performance of Employees (EP) shows the CR value and the $\mathrm{p}$ value that has fulfilled the requirements for $\mathrm{HA}$ acceptance, namely a $\mathrm{CR}$ value greater than 1.96 and a smaller probability than 0.05 . Thus it can be stated that the Effect of Knowledge Management (KM), Occupational Self-Efficacy (OS), on employee performance (EP) are significant.

3. The Effect of Learning Organization (LO), on Employee Performance (EP) shows a CR value of 0.644 and with a probability of 0.519 . Both of these values have not yet met the requirements for accepting $\mathrm{Ha}$, which are greater than 1.96 and probabilities smaller than 0.05. Thus it can be stated that the Effect of Learning Organization (LO), on Employee Performance (KP) is not significant.

4.Land Dispute Handling Skill can act as a mediating variable to the effect of knowledge management on employee performance. However, because both direct and indirect influences are significant, Land Dispute Handling Skill variable can only be as partial mediator on the influence of these two variables.

5. Because the influence of Occupational Self-Efficacy on Employee Performance through Land Dispute Handling Skill is directly significant and also indirectly significant, so in this case Land Dispute Handling Skill plays as partial mediator variable in mediating the effect of Occupational Self-Efficacy on Employee Performance

6. Because the effect is not significant directly, but through the Land Dispute Handling Skill the influence of Learning Organizational on Employee Performance is significant, then the role of the Land Dispute Handling Skill variable here is as a full mediator.

All these findings verifies the research model formulation and this can contribute to update the theories especially in the management field, and as a reference for the practitioners as well especially for BPN Aceh to reset their policies and strategies. The research novelty lies in the use of land dispute handling skill variable as the specificity of employee skill in BPN Aceh and the limitation resides in the amount of variables and object scope.

From the result, authors provide a recommendation for research object to practically use the research model. To increase the employee performance, the most prioritized variable to be improved is the knowledge management, because its contribution is the greatest one.

\section{REFERENCES}

Azhari, Musnadi, S. and Tabrani, M. (2017) 'Pengaruh Manajemen Pengetahuan, Gaya Kepemimpinan Dan Insentif Terhadap Kinerja Pegawai Serta Implikasinya Terhadap Kinerja Organisasi Pada Kantor Pelayanan Pajak Pratama Banda Aceh', Jurnal Manajemen dan Inovasi, 8(2), pp. 1-14.

Bandura, Al. (1993) 'Perceived Self-Efficacy in Cognitive Development and Functioning', Educational Psychologist, 28(2), pp. 117-148.

Goel, S. et al. (2010) 'Predicting consumer behavior with Web search', in Proceeding of the National Academy of Sciences of the United Stated of America. United States: PNAS, pp. 17486-17490. doi: https://doi.org/10.1073/pnas.1005962107.

Jex, S. M. et al. (2001) 'The impact of self-efficacy on stressor-strain relations: Coping style as 


\section{International Journal of Business Management and Economic Review}

Vol. 3, No. 04; 2020

ISSN: 2581-4664

an explanatory mechanism', Journal of Applied Psychology, 86(3), pp. 401-409. doi: https://doi.org/10.1037/0021-9010.86.3.401.

Jønsson, T., Jain, A. K. and Jeppesen, H. J. (2013) 'The employees' participation in leadership tasks during organizational restructuring: The case of a hospital merger', in The 16th Congress of the European Association of Work and Organizational Psychology. Münster, Germany: School Of Business And Social Sciences Aarhus University.

Kamen, C. et al. (2013) 'General self-efficacy in relation to unprotected sexual encounters among persons living with HIV', Journal of Health Psychology, 18(5), pp. 658-666. doi: $10.1177 / 1359105312454039$.

Khandekar, A. and Sharma, A. (2006) 'Organizational learning and performance: Understanding Indian scenario in present global context', Education and Training, 48(8-9), pp. 682-692. doi: 10.1108/00400910610710092.

Mystakidou, K. et al. (2013) 'Relationship of general self-efficacy with anxiety, symptom severity and quality of life in cancer patients before and after radiotherapy treatment', Psycho-Oncology, 22(5), pp. 1089-1095. doi: 10.1002/pon.3106.

Ningtyas, D. C. W., Suryono, A. and Sukanto (2014) 'Impelementasi Organisasi Pembelajaran Dalam Pengembangan Penguatan Pengelolaan Keuangan Sektor Publik (Studi tentang Program The Australia Indonesia Partnership for ecentralization (AIPD) di Badan Perencanaan Pembangunan Daerah Kabupaten Malang)', Jurnal Administrasi Publik (JAP), 2(3), pp. 394-399.

Pérez López, S., Manuel Montes Peón, J. and José Vazquez Ordás, C. (2005) 'Organizational learning as a determining factor in business performance', The learning organization. Emerald Group Publishing Limited, 12(3), pp. 227-245.

Rivai, V. and Sagala, E. J. (2014) Manajemen Sumber Daya Manusia untuk Perusahaan: Dari Teori ke Praktik. 3rd edn. Jakarta: Rajawali Pers.

Salwa, A., Away, Y. and Tabrani, M. (2018) 'Pengaruh Komitmen, Integritas Dan Kompetensi Terhadap Kinerja Pegawai Serta Dampaknya Pada Kinerja Komisi Independen Pemilihan (KIP) Aceh', Jurnal Magister Manajemen, 2(1), pp. 58-67.

Scholz, U. et al. (2002) 'Is general self-efficacy a universal construct? Psychometric findings from 25 countries', European Journal of Psychological Assessment, 18(3), pp. 242-251. doi: https://doi.org/10.1027//1015-5759.18.3.242.

Stata, R. (1989) 'Organizational Learning -- The Key to Management Innovation', Sloan Management Review, 63(Spring).

Taylor, K. M. and Betz, N. E. (1983) 'Applications of self-efficacy theory to the understanding and treatment of career indecision', Journal of Vocational Behavior, 22(1), pp. 63-81. doi: https://doi.org/10.1016/0001-8791(83)90006-4.

Yasir, M. and Majid, A. (2017) 'Impact of knowledge management enablers on knowledge sharing: Is trust a missing link in SMEs of emerging economies?', World Journal of Entrepreneurship, Management and Sustainable Development, 13(1), pp. 16-33. doi: https://doi.org/10.1108/WJEMSD-02-2016-0010.

Yousef, D. A. (2000) 'Organizational commitment: a mediator of the relationships of leadership behavior with job satisfaction and performance in a non-western country', Journal of Managerial Psychology, 15(1), pp. 6-24. doi: 10.1108/02683940010305270. 